\author{
Mateusz Kubicki
}

\title{
FLOTA KUTROWA PORTÓW PÓŁWYSPU HELSKIEGO 2004-2016
}

\begin{abstract}
Streszczenie
Celem artykułu jest prezentacja zjawisk, które zaszły we flocie kutrowej (do 2014 roku segment jednostek długości 15 m i więcej od 2015 roku segment $12 \mathrm{~m}$ i więcej) rozmieszczonej na Półwyspie Helskim w latach 2004-2016. W pierwszej części omówiono ogólne wskaźniki charakteryzujące polską flotę kutrową na Morzu Bałtyckim oraz rozmieszczenie kutrów wyrażone w sztukach w trzech badanych portach: Helu, Jastarni oraz Władysławowie. W drugiej części artykułu opisano szczegółowe dane prezentujące jednostki zarejestrowane w porcie Hel. Omówiono udział floty w segmencie kutrów zarejestrowanych na Półwyspie oraz w odniesieniu do wszystkich eksploatowanych na Morzu Bałtyckim, łączny tonaż wyrażony w GT oraz moc wyrażoną w kW. Trzecia część artykułu prezentuje analogiczną analizę, aczkolwiek przeprowadzoną dla jednostek zarejestrowanych w Jastarni. W czwartej części omówiono identyczne dane dla kutrów stacjonujących we Władysławowie.
\end{abstract}

Słowa kluczowe: łowisko, rybołówstwo, przełowienie

\section{Wstęp}

Polskie rybołówstwo morskie, korzystające z wydajnych łowisk Morza Bałtyckiego, posiada na jego wybrzeżu szereg baz, z których kutry i łodzie wyruszają na połów. Branża ta jest ważna z punktu kulturowego, społecznego oraz podkreśla prestiż Polski, jako kraju eksploatującego żywe zasoby morza. W całym tym systemie ma swoje miejsce także Półwysep Helski, który od setek lat był naturalną bazą dla rybołówstwa, czego najlepszym potwierdzeniem jest fakt, że na odcinku lądu znajdują się trzy porty: Hel, Jastarnia, Władysławowo oraz przystań rybacka w Kuźnicy. Wybór tak wąskiego przedmiotu opracowania pozwala 
na lepszą prezentację zjawiska wykorzystania baz w Helu, Jastarni oraz Władysławowie przez polską flotę kutrową na Morzu Bałtyckim. Bardzo istotny wpływ na omawiane zagadnienie miała akcesja Polski do Unii Europejskiej w 2004 roku. Krótko po finalizacji wejścia do UE rozpoczęto realizację procesu stopniowego ograniczania potencjału połowowego krajowej floty rybackiej, aczkolwiek największe redukcje $\mathrm{w}$ stosunku do liczby jednostek $\mathrm{w}$ danym przedziale długości dotyczyły floty jednostek powyżej $15 \mathrm{~m}$ długości, zdaniem UE, zbyt rozbudowanej względem przyznanych Polsce limitów połowowych określających maksymalny odłów poszczególnych gatunków ryb. To właśnie zapisy WPR (Wspólnej Polityki Rybackiej), unijnego instrumentu zarządzania rybołówstwem, stały u podstaw podejmowanych decyzji. Dalsze zmiany ograniczonego potencjału floty kutrowej były skutkiem postępujących procesów modernizacji poszczególnych jednostek, które w wielu przypadkach przyczyniły się do wzrostu tonażu oraz mocy poszczególnych kutrów, wpływając niewątpliwie na dane zbiorcze dotyczące floty bazującej w poszczególnych portach Półwyspu Helskiego.

W celu zachowania przejrzystości wywodu i dostosowania do aktualnie obowiązujących $\mathrm{w}$ ekonomice rybołówstwa standardów należy wskazać pewne obostrzenia badawcze. Jednym z nich jest synonimiczne używanie pojęcia „kutra rybackiego". W przypadku poniżeszego wywodu odnosi się ono do jednostek znajdujących się $\mathrm{w}$ przedziale długości $15 \mathrm{~m}$ i większych oraz $12 \mathrm{~m}$ i większych. Pierwsza wielkość dotyczy okresu 2004-2014. Druga natomiast odnosi się do pojęcia kutra od 2015 roku, kiedy w polskich wydawnictwach wprowadzono w życie oficjalny podział segmentowy, rezygnując ze stosowanego wcześniej historycznego. Aktualnie wprowadzane zmiany należy uznać za okres przejściowy klasyfikacji. Należy nadmienić, że w Polsce pojęcie „kutra” nadal egzysuje obok kategorii długości wprowadzanych przez UE. Prezentowane liczby w większości pochodzą lub zostały wyliczone na podstawie danych zawartych w kolejnych opracowaniach z serii „Morska Gospodarka Rybna”.

\section{Polska flota kutrowa zarejestrowana w portach Półwyspu Helskiego w latach 2004-2016}

Analiza wielkości floty kutrowej pozwala na wyciagnięcie wniosków dotyczących bardzo dużej zmienności w prezentowanym odcinku czasowym. Należy nadmienić, że największy wpływ na kształt badanej zmiennej miała akcesja Polski do Unii Europejskiej w maju 2004 r., i związany z nią program dostosowania nakładu połowowego do możliwości zrównoważonej eksploatacji łowisk Morza Bałtyckiego. W pierwszym zaprezentowanym na rysunku 1, 2004 roku łącznie badana zbiorowość składała się z 398 jednostek, co było najwyższym wynikiem w omawianym okresie (S. Szostak, E. Kuzebski, T. Budny, 2005, s. 13; S. Szostak, 2005, s. 9; E. Kuzebski, 2007, s. 8). Po zakończonym pod koniec lat 90. XX wieku procesie prywatyzacji polskiej floty kutrowej na Morzu Bałtyckim prywatni ar- 
matorzy eksploatowali ponad 400 jednostek. W momencie akcesji Polski do UE część z kutrów znajdowała się w złym stanie technicznym. Należy nadmienić, że złomowano także jednostki stosunkowo nowe. Przyczyn redukcji należy dopatrywać się głównie $\mathrm{w}$ wypłacaniu odszkodowań zależnych od wielkości jednostek, zaawansowanym wieku armatorów oraz braku następców. Do największego obniżenia się liczby kutrów znajdujących się w eksploatacji doszło w 2005 r., kiedy flota zmniejszyła się o 37,44\% względem poprzedniego roku. W 2005 r. flotę kutrową na M. Bałtyckim tworzyło łącznie 249 jednostek (S. Szostak, E. Kuzebski, T. Budny, 2006, s. 15; S. Szostak, 2006, s. 11; E. Kuzebski, 2007, s. 8).

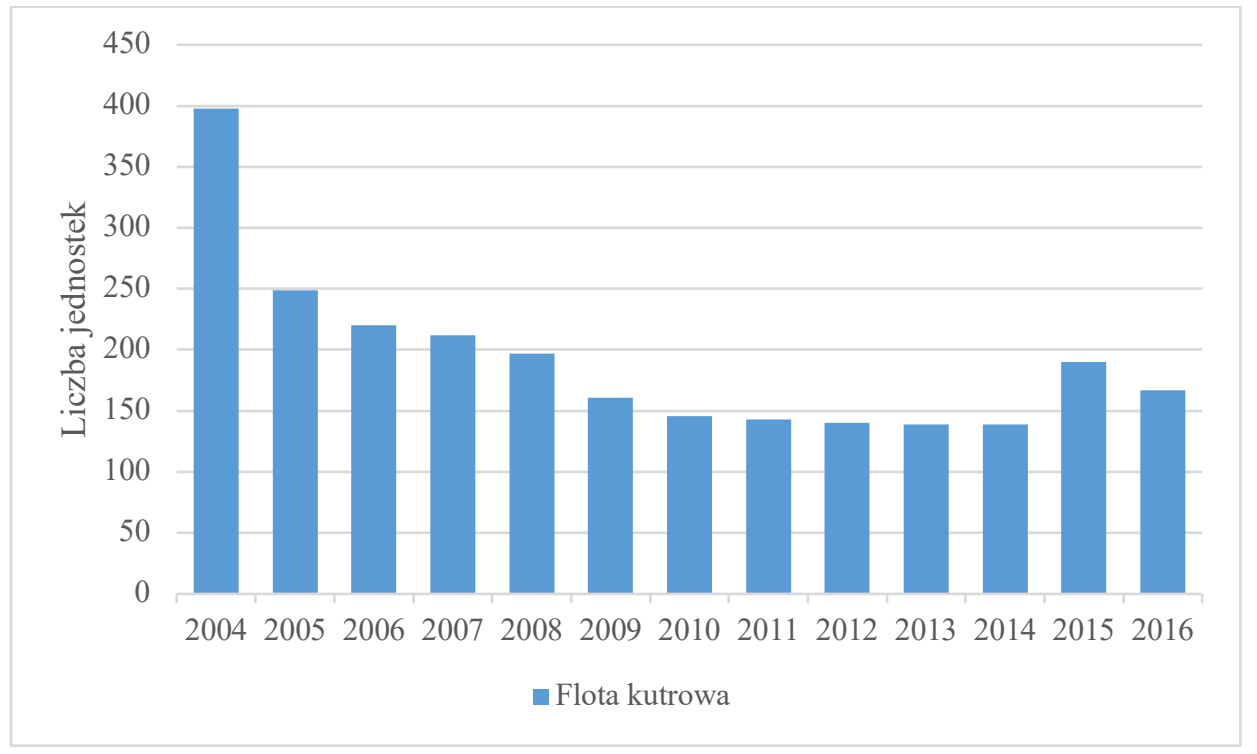

Rysunek 1. Liczebność polskiej floty kutrowej operującej na łowiskach Morza Bałtyckiego w latach 2004-2016 [szt.]

W przypadku polskiej floty na Morzu Battyckim do 2014 roku jako kutry określano jednostki długości $15 \mathrm{~m}$ i więcej. Od 2015 roku do tej kategorii zaliczano jednoski o długości $12 \mathrm{~m}$ i więcej.

Źródło: Opracowanie własne na podstawie: Morska Gospodarka Rybna w latach 2004-2016, (2005-2017) Gdynia: Morski Instytut Rybacki.

Rok 2006 cechował się dalszym spadkiem wolumenu jednostek znajdujących się w eksploatacji, który zmniejszył się o dalsze 11,65\% względem poprzedniego roku. W 2006 r. flotę kutrową na M. Bałtyckim tworzyło łącznie 220 jednostek (S. Szostak, E. Kuzebski, T. Budny, 2007, s. 15; E. Kuzebski, 2007, s. 8; S. Szostak, 2006, s. 10). Następny analizowany rok - 2007 przyniósł niewielki spadek liczby kutrów, która zmniejszyła się o 3,64\% względem poprzedniego roku. W 2007 r. flotę kutrową na M. Bałtyckim tworzyło łącznie 212 jednostek (S. Szo- 
stak, E. Kuzebski, M. Rakowski, 2008, s. 15; S. Szostak, 2008, s. 5). W przypadku kolejnego prezentowanego na rysunku 1 roku doszło do dalszego obniżenia się liczebności floty kutrowej o 7,08\% względem poprzedniego roku. W 2008 r. flotę kutrową na M. Bałtyckim tworzyło łącznie 197 jednostek. (S. Szostak, E. Kuzebski, M. Rakowski, 2009, s. 17; S. Szostak, 2009, s. 9). Rok 2009 cechował się dużym spadkiem liczby pozostających w eksploatacji kutrów, która obniżyła się o dalsze 18,27\% względem poprzedniego roku. W 2009 r. flotę kutrową na M. Bałtyckim tworzyło łącznie 161 jednostek (S. Szostak, M. Rakowski, T. Budny, 2010, s. 15). Kolejny badany na rysunku 1 rok przyniósł dla floty kutrowej dalsze obniżenie się liczby pozostających w eksploatacji jednostek, która była mniejsza o 9,32\% względem poprzedniego roku. W $2010 \mathrm{r}$. flotę kutrową na M. Bałtyckim tworzyło łącznie 146 jednostek (S. Szostak, M. Rakowski, T. Budny, 2011, s. 15; S. Szostak 2012, s. 6). Lata 2011-2012 cechowały się niewielkim spadkiem wielkości floty kutrowej, oscylującym w granicach odpowiednio 2,05\% oraz 2,10\% względem poprzedniego roku. W $2011 \mathrm{r}$. flotę kutrową na M. Bałtyckim tworzyło łącznie 143 jednostki, w 2012 r. było to 140 jednostek (S. Szostak, M. Rakowski, T. Budny, 2012, s. 15; S. Szostak, M. Rakowski, T. Budny, 2013, s. 15; S. Szostak, 2012, s. 6; S. Szostak, 2014, s. 16). Rok 2013 przyniósł nieznaczny spadek liczby jednostek, która obniżyła się o 0,71\% względem poprzedniego roku. W $2013 \mathrm{r}$. flotę kutrową na M. Bałtyckim tworzyło łącznie 139 jednostek (S. Szostak, M. Rakowski, T. Budny, 2014, s. 15; S. Szostak, 2014, s. 16), a wielkość ta nie uległa zmianie na koniec 2014 roku (S. Szostak, M. Rakowski, T. Budny, 2015, s. 15; S. Szostak, 2015, s. 15). Kolejny przedstawiony na rysunku 12015 rok cechował się zwiększeniem liczby jednostek tworzących polską flotę kutrową której liczebność wzrosła o 36,69\% względem poprzedniego roku. W $2015 \mathrm{r}$. flotę kutrową na M. Bałtyckim tworzyło łącznie 190 jednostek (T. Budny, M. Kieliszewska, J. Krupska, 2017, s. 29). Sytuacja z lat 2015-2016 wynikała z faktycznej rezygnacji z historycznego podziału i wprowadzeniu $\mathrm{w}$ polskich opracowaniach kategorii jednostek używanych od dawna w UE, gdzie kutrami określono już te o długości $12 \mathrm{~m}$ i więcej. Ostatni badany - 2016 rok cechował się spadkiem łącznej liczby jednostek pozostających w eksploatacji o 12,11\% względem poprzedniego roku. W 2016 r. flotę kutrową na M. Bałtyckim tworzyło łącznie 167 jednostek.

Z punktu widzenia tego opracowania niezwykle istotnym czynnikiem wymagającym omówienia jest rozmieszczenie floty kutrowej w poszczególnych portach Półwyspu Helskiego. Aby lepiej zrozumieć przebieg badanego zjawiska, należy przede wszystkim wskazać, że największa liczba kutrów na Półwyspie Helskim przez cały badany okres posiadała jako port rejestracji Władysławowo, a drugą lokatę zajmował pod tym względem port w Jastarni. Na skutek większego niż $\mathrm{w}$ pozostałych badanych portach wykorzystania programu redukcji floty rybackiej przez armatorów kutrów zarejestrowanych w Helu, w porcie tym zostało najmniej jednostek powyżej $12 \mathrm{~m}$ długości. Rysunek 2 przyporządkowuje 
jednostki, uwzględniając ich port rejestracji, a nie miejsce, z którego wychodziły na łowisko - $\mathrm{w}$ wielu przypadku zupełnie odmienne od bazy macierzystej.

Opis floty kutrowej zarejestrowanej w portach położonych na Półwyspie Helskim, ograniczony poprzez wybór trzech wskazanych wcześniej portów, prowadzi do pewnych wniosków. W pierwszym analizowanym na rysunku 2 2004 roku, łączna liczba jednostek wynosiła 125, stanowiąc jednocześnie 31,41\% całości floty kutrowej operującej na Morzu Bałtyckim. W 2004 r. w Helu bazowało 20 kutrów, w Jastarni 20 kutrów, we Władysławowie 85 kutrów.

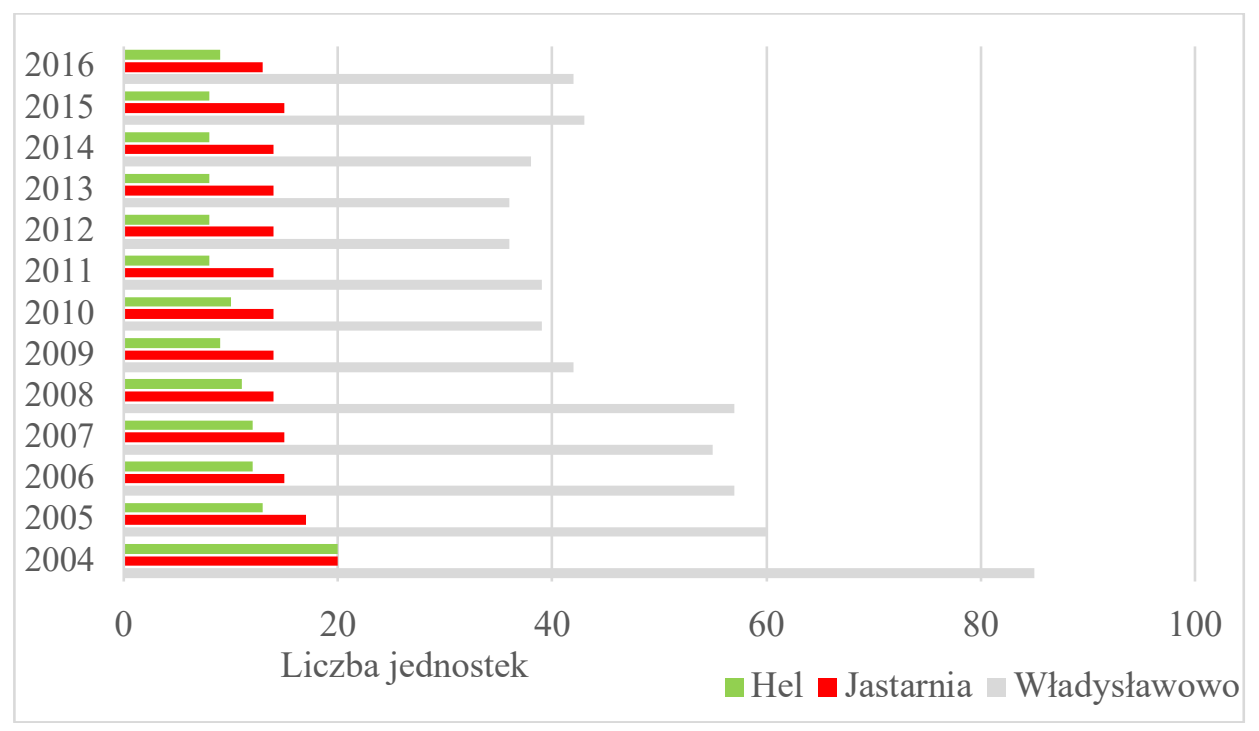

Rysunek 2. Liczba kutrów zarejestrowanych w portach Półwyspu Helskiego w latach

$$
\text { 2004-2016 [szt.] }
$$

Źródło: Opracowanie własne na podstawie: Morska Gospodarka Rybna w latach 2004-2016, (2005-2017), Gdynia: Morski Instytut Rybacki.

Rok 2005 przyniósł niewielki wzrost udziału jednostek posiadających jako port rejestracji jedno z trzech miast do poziomu $36,14 \%$ całości polskiej floty kutrowej. W 2005 r. w Helu bazowało 13 kutrów, w Jastarni 17 kutrów, we Władysławowie 60 kutrów. W ciągu dwóch następnych lat (2006-2007) kutry z Helu, Jastarni i Władysławowa stanowiły ponad 38\% wszystkich jednostek tworzących polską flotę kutrową na Morzu Bałtyckim. W 2006 r. w Helu bazowało 12 kutrów, w Jastarni 15 kutrów, zaś we Władysławowie 57 kutrów. W 2007 r. zmianie uległa tylko liczba jednostek posiadających jako port rejestracji Władysławowo, obniżając się do poziomu 55 jednostek. Od 2008 roku następował dalszy wzrost udziału jednostek z portów Półwyspu Helskiego w całkowitej liczbie kutrów eksploatowanych przez polską flotę rybacką na Morzu Bałtyckim. Wynosił on ponad 40\%, gdzie najniższa wartość została osiagnięta w 2009 r. (40,37\%), a naj- 
wyższa w 2014 r. (43,17\%). W 2008 r. w Helu bazowało 11 kutrów, w Jastarni 14 kutrów, zaś we Władysławowie 57 kutrów. W 2009 r. w Helu bazowało 9 kutrów, w Jastarni 14 kutrów, we Władysławowie 42 kutry. W 2010 r. w Helu bazowało 10 kutrów, w Jastarni 14 kutrów, we Władysławowie 39 kutrów. W 2011 r. w Helu bazowało 8 kutrów i liczba ta nie zmieniła się do 2014 r., w Jastarni bazowało 14 kutrów i liczba ta również nie zmieniła się do końca 2014 r., we Władysławowie bazowało 39 jednostek. W 2012 i 2013 r. we Władysławowie bazowało 36 jednostek, a w 2014 r. 38 jednostek. Przedostatni analizowany na rysunku 2 2015 rok cechował się dużym spadkiem łącznej liczby jednostek $\mathrm{z}$ badanych portów do poziomu 34,74\% całości. W 2015 r. w Helu bazowało 8 kutrów, w Jastarni 15 kutrów, we Władysławowie 43 kutry. Wynikało to w dużej mierze ze zmian w klasyfikcaji jednostek, gdzie obniżono długość kutrów do $12 \mathrm{~m}$ i więcej. Ostatni badany rok przyniósł wzrost udziału kutrów posiadających bazy macierzyste we wskazanych portach do 38,32\% wszystkich jednostek tworzących prezentowaną kategorię. W 2016 r. w Helu bazowało 9 kutrów, w Jastarni 13 kutrów, we Władysławowie 42 kutry. Należy wskazać, że w w 2016 roku również posługiwano się zmienioną kategoryzacją jednostek klasyfikowanych jak kutry.

\section{Flota kutrowa zarejestrowana w porcie Hel w latach 2004-2016}

Zgodnie z przyjętymi obostrzeniami, niniejszy artykuł prezentuje zagadnienie z uwzględnieniem czynnika geograficznego rozmieszczenia obiektów. Pierwszym opisywanym portem macierzystym floty kutrowej na Półwyspie Helskim jest umiejscowiony na samych końcu cypla port w Helu. Wybudowany w II połowie XIX wieku przez pruskie władze był jedną z najważniejszych, strategicznych inwestycji. Infrastruktura portowa była wielokrotnie modernizowana i rozbudowywana, a ostatni kapitalny remont miał miejsce w latach 1989-2005. Do największych zalet helskiego portu należy między innymi bardzo dobre położenie, które obok osłony od wiatrów z kierunków północnych, zapewnia całkowita swobodę żeglugi i znaczne ograniczenie zagrożenia spowodowanego zalodzeniem (D. Duda, B. Wandtke, 1993, s. 11-12). Dodatkowo, port umożliwia stosunkowo szybkie dotarcie kutrów do wydajnych łowisk szprota i śledzia, eksploatowanych zwłaszcza zimą i wiosną.

Zaprezentowane na rysunku 3 dane odnoszą się do procentowego udziału kutrów zarejestrowanych w Helu wśród tych posiadających bazy na Półwyspie Helskim oraz wobec wszystkich jednostek w Rejestrze Statków Rybackich (https://mgm.gov.pl/pl/rybolowstwo/;https://www.gov.pl/gospodarkamorska/res tr- statkow-rybackich), eksploatowanych przez polskich rybaków na akwenie Morza Bałtyckiego. 


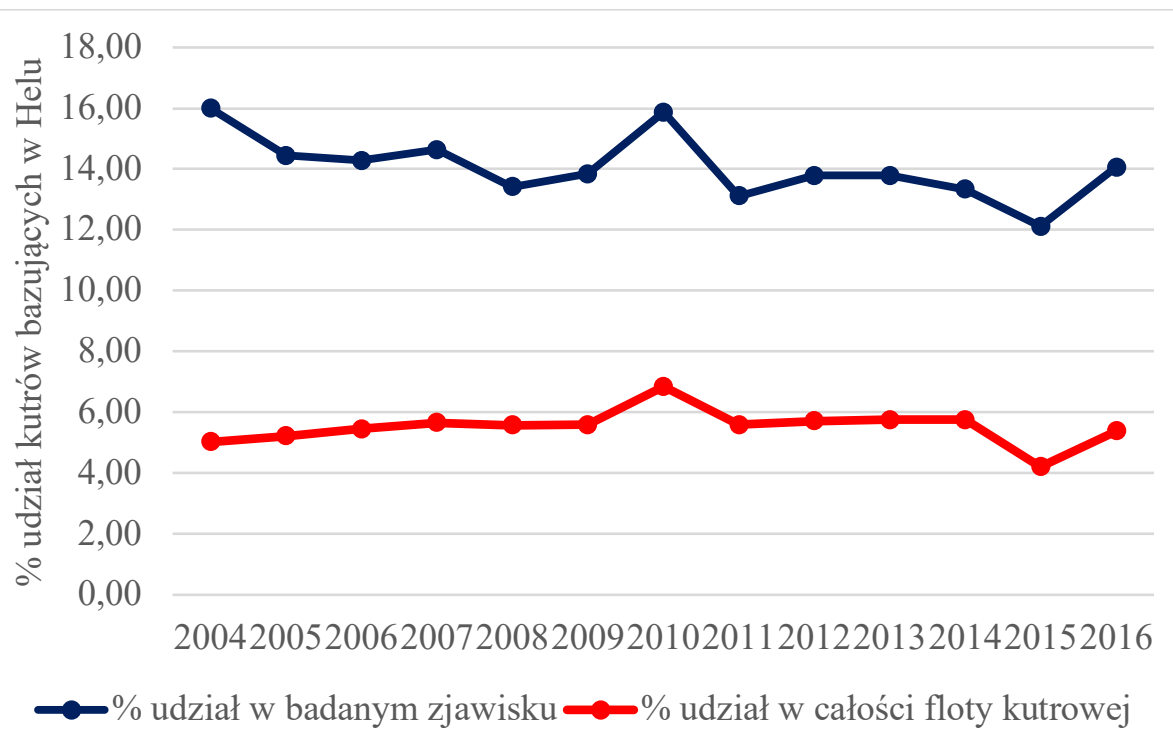

Rysunek 3. Udział kutrów zarejestrowanych w porcie Hel w analizowanym segmencie oraz w całości polskiej floty rybackiej operującej na Morzu Bałtyckim w latach 2004-2016

[\%]

Źródło: Opracowanie własne na podstawie: Morska Gospodarka Rybna w latach 2004-2016, (2005-2017), Gdynia: Morski Instytut Rybacki.

W przypadku badania pierwszej wartości jej udział procentowy w latach 2004-2016 oscylował $\mathrm{w}$ granicach $12-16 \%$, osiagając najniższą wartość $12,12 \%$ (2015 rok), przy tym najwyższa przypadała na 2004 rok - 16,00\%. W 2004 r. na Półwyspie Helskim eksploatowano 125 kutrów, w 2005 r. 90 kutrów, w 2006 r. 84 kutry, 2007 r. 82 kutry, 2008 r. 82 kutry, 2009 r. 65 kutrów, 2010 r. 63 kutry, 2011 r. 61 kutrów, 2012 i 2013 r. 58 kutrów, 2014 r. 60 kutrów, 2015 r. 66 kutrów, 2016 r. 64 kutry (E. Jackowski, 2005, s. 9). Tak niewielka rozbieżność danych wynikała w dużej mierze ze zmniejszenia się liczby kutrów zarejestrowanych w Helu wraz ze spadkiem liczby jednostek posiadających porty macierzyste na Półwyspie.

Zbliżone dane są w przypadku porównania helskiej floty kutrowej ze wszystkimi kutrami eksploatowanymi przez polską flotę na Morzu Bałtyckim (patrz rysunek 1). W przypadku analizy większość wartości oscylowała w granicach powyżej $5 \%$ całości grupy jednostek. Należy wskazać, że najniższy udział miał miejsce w 2015 r. (4,21\%), a najwyższy w 2010 r. (6,85\% całości). Niewątpliwie badane zmienne były ściśle związane z przebiegiem procesu restrukturyzacji floty mającym miejsce po 2004 roku oraz późniejszych zmian w klasyfikacji przypadających na 2015 rok. 
Analizując dane zamieszczone w tabeli 1, można wyciągnąć pewne wnioski dotyczące względnej stałości tonażu floty zarejestrowanej w porcie Hel. Najwyższa wartość przypadająca na 2004 rok stanowiła jednocześnie 6,65\% tonażu całej floty kutrowej eksploatowanej przez polskich rybaków na wodach Morza Bałtyckiego i była ściśle związana z liczbą jednostek, która była najwyższa w całym badanym okresie.

Tabela 1. Tonaż $[\mathrm{GT}]$ oraz moc silników $[\mathrm{kW}$ ] floty zarejestrowanej w porcie Hel na tle całej polskiej floty kutrowej operującej na Morzu Bałtyckim w latach 2004-2016

\begin{tabular}{|c|c|c|c|c|}
\hline \multirow{2}{*}{ Rok } & \multicolumn{3}{|c|}{ Tonaż floty kutrowej [GT] } & \multicolumn{2}{c|}{ Moc silników floty kutrowej } \\
\cline { 2 - 5 } & Hel & Całość floty & Hel & Całość floty \\
\hline 2004 & 2384 & 33040 & 6344 & 95332 \\
\hline 2005 & 1530 & 19848 & 4576 & 62842 \\
\hline 2006 & 1434 & 17643 & 4445 & 56488 \\
\hline 2007 & 1434 & 17127 & 4445 & 55204 \\
\hline 2008 & 1297 & 15716 & 4025 & 50789 \\
\hline 2009 & 1010 & 12887 & 3185 & 42470 \\
\hline 2010 & 1255 & 11797 & 3844 & 38197 \\
\hline 2011 & 972 & 11640 & 3005 & 37032 \\
\hline 2012 & 972 & 11644 & 3005 & 36186 \\
\hline 2013 & 1115 & 12205 & 3005 & 36210 \\
\hline 2014 & 1150 & 12323 & 3005 & 36247 \\
\hline $2015^{*}$ & 1176 & 13796 & 3005 & 42714 \\
\hline $2016^{*}$ & 1321 & 13116 & 3425 & 39724 \\
\hline
\end{tabular}

* Jednostki powyżej $12 \mathrm{~m}$ długości

Źródło: Morska Gospodarka Rybna w latach 2004-2016, (2005-2017), Gdynia: Morski Instytut Rybacki.

Lata późniejsze cechowały się stopniowym obniżaniem analizowanego czynnika, aczkolwiek współczynnik udziału kutrów zarejestrowanych w Helu w całości tonażu polskiej floty kutrowej do 2007 roku wzrastał. W 2005 r. tonaż floty wskazującej Hel jako port rejestracji stanowił 7,71\% całości, w 2006 r. 8,13\%, w 2007 r. 8,37\%. W okresie przypadającym na lata 2008-2009 doszło do niewielkiego obniżenia się udziału helskich kutrów w całości GT prezentowanej grupy jednostek. W 2008 r. tonaż floty posiadającej Hel jako port macierzysty stanowił 8,25\% całości, w 2009 r. 7,84\%. Jako wartość najwyższą należy wskazać współczynnik osiagnięty przez helską flotę w 2010 roku, kiedy jednostki zarejestrowane w tym porcie stanowiły 10,64\% całości polskiej floty kutrowej operującej na akwenie Morza Bałtyckiego. Po niewielkim zmniejszeniu udziału do poziomu 8,35\%, przypadającym na 2011 rok, w latach kolejnych doszło do powolnego wzrostu, gdzie za moment szczytowy należy uznać rok 
2014. W 2012 r. tonaż floty posiadającej Hel jako port macierzysty stanowił 8,35\% całości, w 2013 r. 9,14\%, w 2014 r. 9,33\%. Ostatnie prezentowane w tabeli 1 wyniki cechowały się bardzo dużą zmiennością udziału helskich jednostek, wynikającą wyłącznie z obniżenia długości kategorii kutrów do $12 \mathrm{~m}$ i więcej w całości kutrów operujących na Bałtyku. W $2015 \mathrm{r}$. tonaż floty posiadającej Hel jako port macierzysty stanowił 8,52\% całości, w 2016 r. 10,07\%.

Drugim czynnikiem wymagającym omówienia, a zaprezentowanym w tabeli 1, jest moc floty kutrów zarejestrowanych w porcie Hel na tle wszystkich polskich kutrów bałtyckich. Najniższy współczynnik analizowanej wartości przypadał na rok 2004, aczkolwiek było to ściśle związane z dużą liczbą jednostek pozostających w czynnej służbie (S. Szostak i in., 2005, s. 18). Następny okres przypadający na lata 2005-2009 cechował się, obok wzrostu udziału, niewielkimi odchyleniami partycypacji helskich jednostek na tle całości polskiej floty kutrowej, który oscylował na poziomie między 7 a 8\%. W 2005 r. moc floty posiadającej Hel jako port macierzysty stanowiła 7,28\% całości, w 2006 r. 7,87\%, w 2007 r. 8,05\%, w 2008 r. 7,92\%, w 2009 r. 7,50\%. Rok 2010 przyniósł wzrost udziału jednostek wskazujących na Hel jako port macierzysty do poziomu 10,06\%, co jednocześnie było wartością szczytową dla całego badanego odcinka czasowego (S. Szostak i in., 2011, s. 18). Okres następny, przypadający na lata 2011-2016, cechował się niewielkimi odchyleniami udziału, gdzie najniższa wartość przypadała na 2015 rok, co wiązało się ze zmianą kategorii długości kutrów i obniżeniem jej do $12 \mathrm{~m}$ i więcej. W $2011 \mathrm{r}$. moc floty posiadającej Hel jako port macierzysty stanowiła 8,11\% całości, w 2012 r. 8,30\%, w 2013 r. 8,30\%, w 2014 r. 8,29\%, w 2015 r. 7,04\%, w 2016 r. 8,62\%.

\section{Flota kutrowa zarejestrowana w porcie Jastarnia w latach 2004-2016}

Zgodnie z przyjętym geograficznym kryterium rozmieszczenia, drugim portem kutrowym, który zostanie omówiony na łamach niniejszego artykułu jest Jastarnia. Położony od strony Zatoki Puckiej, w odległości około $15 \mathrm{~km}$ od Helu, stanowi bazę dla mniejszych jednostek. Został on wybudowany na przestrzeni lat 20. i 30. XX wieku dla kutrów i łodzi rybackich oraz żeglarzy. Port ten podczas użytkowania był modernizowany dwukrotnie. Pierwszy gruntowny remont, mający miejsce $\mathrm{w}$ latach $70 . \mathrm{XX}$ wieku, w znacznym stopniu usprawnił walory użytkowe budowli. Druga przebudowa została zrealizowana po akcesji Polski do Unii Europejskiej, zmieniając całkowicie dotychczasowy wygląd i zwiększając znacznie potencjał jastarnickiego portu. 


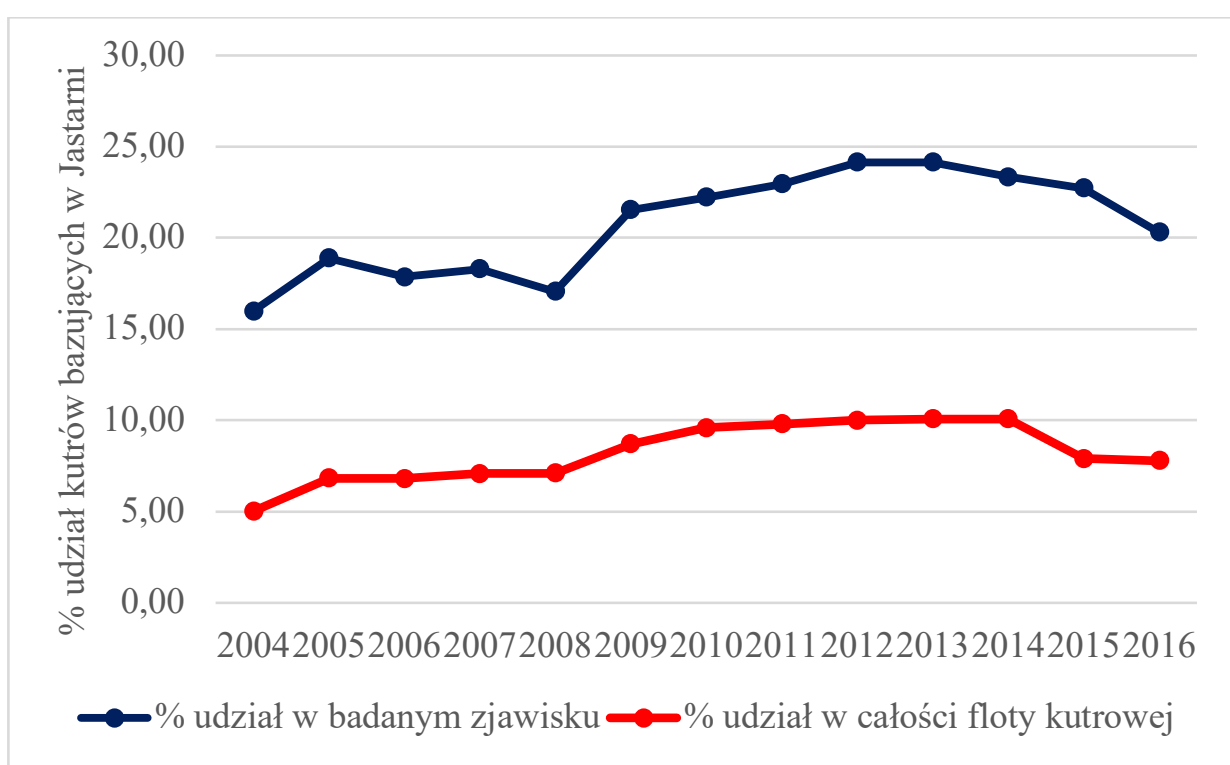

Rysunek 4. Udział kutrów zarejestrowanych w porcie Jastarnia w analizowanym segmencie oraz w całości polskiej floty kutrowej operującej na Morzu Bałtyckim w latach 2004-2016 [\%]

Źródło: Opracowanie własne na podstawie: Morska Gospodarka Rybna w latach 2004-2016 (2005-2017), Gdynia: Morski Instytut Rybacki.

Zaprezentowane na rysunku 4 dane dotyczące udziału kutrów bazujących na stałe w Jastarni na tle jednostek eksploatowanych na Półwyspie Helskim oraz wszystkich tworzących polską flotę kutrową na Morzu Bałtyckim przedstawia się zupełnie inaczej niż dane analizowane na rysunkach 3 i 5 . Cechują się one zmiennością trendu, który od początkowego spadku, w okresie późniejszym wzrasta, aby ostatecznie stopniowo maleć.

Dokonując analizy udziału jednostek zarejestrowanych w porcie Jastarnia $\mathrm{w}$ całości polskich kutrów (do 2014 roku 15 m i więcej, od 2015 roku 12 m i więcej) eksploatowanych na Półwyspie Helskim w roku bazowym - 2004, otrzymuje się identyczny wynik jak w przypadku helskiej floty, tj. 16,00\% (S. Szostak i in., 2005, s. 20; E. Jackowski, 2005, s. 9). Lata 2005-2008 cechowały się udziałem kutrów w prezentowanym zagadnieniu oscylującym na poziomie 17-18\%. W 2005 r. kutry bazujące $\mathrm{w}$ porcie Jastarnia stanowiły $18,89 \%$ wszystkich eksploatowanych na Półwyspie Helskim, w 2006 r. 17,86\%, w 2007 r. 18,29\%, w 2008 r. 17,07\%. Okres następny, przypadający na lata 2009-2016, cechował się stałym udziałem jastarnickiej floty na poziomie około $20 \%$, gdzie za wartość szczytową należy uznać lata 2012-2013, kiedy uzyskany współczynnik był najwyższy. W 2009 r. kutry bazujące $\mathrm{w}$ porcie Jastarnia stanowiły $21,54 \%$ wszystkich eksploatowanych na 
Półwyspie Helskim, w 2010 r. 22,22\%, w 2011 r. 22,95\%, w 2012 r. 24,14\%, w 2013 r. 24,14\%, w 2014 r. 23,33\%, w 2015 r. 22,73\%, w 2016 r. 20,31\%. Późniejszy spadek związany był z dokonanym w ramach WPR w 2015 roku rozszerzeniem składu jednostek określanych jako kuter w opracowaniach „Morska Gospodarka Rybna”, obniżającym przedział długości „kutra” na 12 metrów i więcej.

Zupełnie inna sytuacja miała miejsce $\mathrm{w}$ przypadku analizy udziału jednostek bazujących w Jastarni na tle wszystkich kutrów eksploatowanych przez polskich rybaków na Morzu Bałtyckim. W latach 2004-2014 wystąpiła ustawiczna tendencja wzrostowa badanego zjawiska z niewielkim spadkiem rzędu $0,01 \% \mathrm{w}$ 2006 roku. W $2004 \mathrm{r}$. kutry bazujące w Jastarni stanowily 5,03\% wszystkich eksploatowanych na Morzu Bałtyckim, w 2005 r. 6,83\%, w 2006 r. 6,82\%, w 2007 r. 7,08\%, w 2008 r. 7,11\%, w 2009 r. 8,70\%, w 2010 r. 9,59\%, w 2011 r. 9,79\%, w 2012 r. 10,00\%, w 2013 r. 10,07\%, w 2014 r. 10,07\%. Ostatnie dwa lata prezentowane na rysunku 4 cechowały się ubytkiem badanych wartości do poziomu poniżej $8 \%$, co było związane ze wskazaną wcześniej zmianą klasyfikacji. W 2015 r. kutry bazujące w Jastarni stanowiły 7,89\% wszystkich eksploatowanych na Morzu Bałtyckim, zaś w 2016 r. 7,78\%.

Analiza tonażu floty [GT] (patrz tab. 2) zarejestrowanej w porcie Jastarnia na tle wszystkich jednostek eksploatowanych na Morzu Bałtyckim uwidoczniła silną tendencję do zachowania pewnej stałości badanych wartości, aczkolwiek wskutek przeprowadzonego procesu redukcji floty współczynnik ten będzie ulegał na przestrzeni czasu stopniowemu wzrostowi. Jednocześnie należy wskazać, że najniższa wartość, wynosząca 2,75\% całości, przypadała na 2004 rok (S. Szostak i in., 2005, s. 18). W latach 2005-2008 udział kutrów zarejestrowanych w Jastarni przekroczył poziom 3\%. W 2005 r. tonaż kutrów bazujących w Jastarni wynosił 3,62\% całości tonażu floty kutrowej na Morzu Bałtyckim, w 2006 r. $3,33 \%$, w 2007 r. 3,43\%, w 2008 r. 3,41\%. Wraz ze stopniowym procesem redukcji potencjału połowowego wzrastał także udział jastarnickich jednostek w całości floty kutrowej. W latach 2009-2016 wynosił on średnio ponad 4\%, przy czym najniższa wartość, tj. 3,99\%, przypadała na 2016 rok. W 2009 r. tonaż kutrów bazujących w Jastarni wynosił 4,16\% całości tonażu floty kutrowej na Morzu Bałtyckim, w 2010 r. 4,54\%, w 2011 r. 4,62\%, w 2012 r. 4,63\%, w 2013 r. 4,58\%, w 2014 r. $4,54 \%$, w 2015 r. $4,23 \%$.

Tabela 2. Tonaż [GT] oraz moc silników [kW] floty zarejestrowanej w porcie Jastarnia na tle całości polskiej floty kutrowej operującej na Morzu Bałtyckim w latach 2004-2016

\begin{tabular}{|c|c|c|c|c|}
\hline \multirow{2}{*}{ Rok } & \multicolumn{2}{|c|}{ Tonaż floty kutrowej [GT] } & \multicolumn{2}{c|}{$\begin{array}{c}\text { Moc silników floty kutrowej } \\
{[\mathrm{kW}]}\end{array}$} \\
\cline { 2 - 5 } & Jastarnia & Całość floty & Jastarnia & Całość floty \\
\hline
\end{tabular}




\begin{tabular}{|l|l|l|l|l|}
\hline 2004 & 908 & 33040 & 3423 & 95332 \\
\hline 2005 & 718 & 19848 & 3257 & 62842 \\
\hline 2006 & 587 & 17643 & 3161 & 56488 \\
\hline 2007 & 587 & 17127 & 3111 & 55204 \\
\hline 2008 & 536 & 15716 & 2990 & 50789 \\
\hline 2009 & 536 & 12887 & 2990 & 42470 \\
\hline 2010 & 536 & 11797 & 2990 & 38197 \\
\hline 2011 & 538 & 11640 & 2990 & 37032 \\
\hline 2012 & 539 & 11644 & 2990 & 36186 \\
\hline 2013 & 559 & 12205 & 2990 & 36210 \\
\hline 2014 & 560 & 12323 & 2990 & 36247 \\
\hline $2015^{*}$ & 584 & 13796 & 3111 & 42714 \\
\hline $2016^{*}$ & 523 & 13116 & 2869 & 39724 \\
\hline
\end{tabular}

* Jednostki powyżej 12 m długości

Źródło: Morska Gospodarka Rybna w latach 2004-2016 (2005-2017), Gdynia: Morski Instytut Rybacki.

W przypadku analizy mocy silników wyrażonych $\mathrm{w} \mathrm{kW}$ na tle całej polskiej floty kutrowej należy wskazać, że czynnik ten osiągnął najniższy poziom w 2004 roku (3,59\%). Uwidoczniła się zależność, że wraz z postępującym procesem redukcji potencjału połowowego floty badana wartość stopniowo wzrastała. Sytuacja taka miała miejsce na przestrzeni lat 2005-2013, gdzie za szczytowe należy uznać 2012 i 2013 rok (8,26\%). W 2005 r. łączna moc kutrów bazujących w Jastarni wynosiła 5,18\% całości mocy polskiej floty kutrowej na Morzu Bałtyckim, w 2006 r. 5,60\%, w 2007 r. 5,64\%, w 2008 r. 5,89\%, w 2009 r. 7,04\%, w 2010 r. 7,83\%, w 2011 r. 8,07\%. Nieustannie od 2014 roku uwidoczniła się stała spadkowa badanego zjawiska, powiązana ze zmianą kategoryzacji segmentów długości kutrów, które w 2016 roku osiągnęło poziom 7,22\% całości mocy floty kutrowej na Morzu Bałtyckim. W 2014 r. łączna moc kutrów bazujących w Jastarni wynosiła 8,25\% całości mocy floty kutrowej na Morzu Bałtyckim, w 2015 r. 7,28\%.

\section{Flota kutrowa zarejestrowana w porcie Władysławowo w latach 2004-2016}

Uwzględniając przyjęte kryterium opisu, ostatnim portem stanowiącym przedmiot analizy jest Władysławowo. Umiejscowione u nasady Półwyspu Helskiego pełni rolę ważnej bazy wypadowej dla polskiego rybołówstwa kutrowego na Morzu Bałtyckim. Budowla ta, oddana do użytku w 1938 roku, stanowi bardzo istotny punkt bazowania dla jednostek pływających. Dodatkowo należy nadmienić, że $\mathrm{w}$ porcie tym nadal funkcjonuje ostatnie państwowe przedsiębiorstwo połowowo-przetwórcze PPiUR "Szkuner" Sp. z o.o. (50 lat „Szkunera”, 2005, s. 18). Mając na uwadze specyfikę rybołówstwa na Mierzei Helskiej, bardzo waż- 
nym jest wskazanie dominującej roli władysławowskiego obiektu jak portu rejestracji dla dużej grupy kutrów.

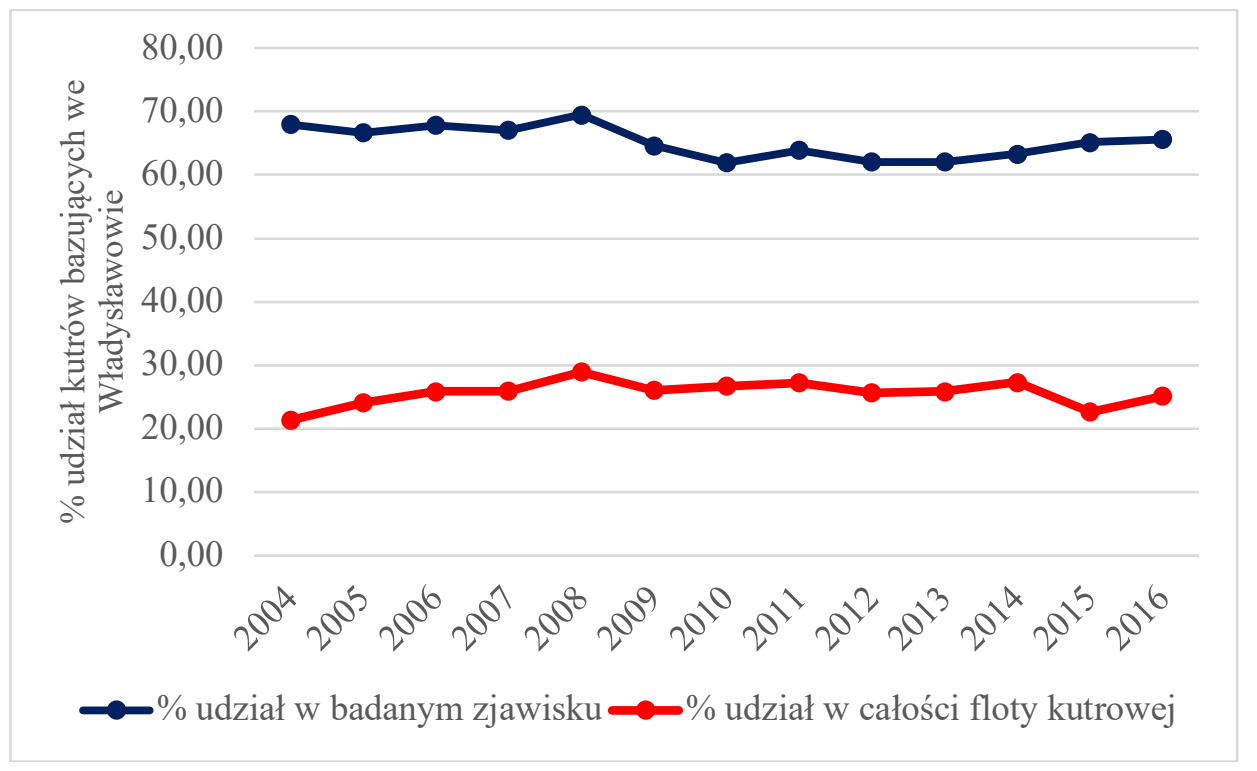

Rysunek 5. Udział kutrów zarejestowanych w porcie Władysławowo w analizowanym segmencie oraz w całości polskiej floty kutrowej operującej na Morzu Bałtyckim w latach 2004-2016 [\%]

Źródło: Opracowanie własne na podstawie: Morska Gospodarka Rybna w latach 2004-2016, (2005-2017), Gdynia: Morski Instytut Rybacki.

Analiza danych zawartych na rysunku 5 pozwala na wyciagnięcie wniosków dotyczących bardzo dużego udziału władysławowskiej floty w segmencie jednostek (do 2015 roku - 15 m i więcej, po 2015 roku 12 m i więcej) zarejestrowanych na Półwyspie Helskim oraz w całości polskiej floty eksploatowanej na Morzu Bałtyckim. W przypadku pierwszej z badanych wartości na przestrzeni lat 2004-2016 oscylowała ona zawsze $\mathrm{w}$ granicach ponad $60 \%$ całości, przy czym wartość najwyższa przypadała na 2004 roku $(68,00 \%)$, a najniższa na 2010 rok (61,90\%). W 2005 roku kutry bazujące we Władysławowie stanowiły 66,67\% wszystkich jednostek zarejestrowanych w portach kutrowych Półwyspu Helskiego, w 2006 r. 67,86\%, w 2007 r. 67,07\%, w 2008 r. 69,51\%, w 2009 r. 64,62\%, w 2011 r. $63,93 \%$, w 2012 r. $62,07 \%$, w 2013 r. $62,07 \%$, w 2014 r. 63,33\%, w 2015 r. $65,15 \%$, w 2016 r. 65,63\%.

W przypadku porównania floty posiadającej Władysławowo jako port rejestracji na tle wszystkich kutrów operujących na Morzu Bałtyckim nasuwają się 
wnioski dotyczące znacznego udziału w prezentowanej na rysunku 5 kategorii. Należy wskazać, że w całym badanym okresie (2004-2016) wynosił on ponad $20 \%$, gdzie najniższa wartość została osiągnięta w 2004 roku, a najwyższa w 2008 roku. W 2004 roku kutry bazujące we Władysławowie stanowiły 21,36\% wszystkich kutrów eksploatowanych przez polskich rybaków na Morzu Bałtyckim, w 2005 r. $24,10 \%$, w 2006 r. $25,91 \%$, w 2007 r. $25,94 \%$, w 2008 r. $28,93 \%$, w 2009 r. $26,09 \%$, w 2010 r. $26,71 \%$, w 2011 r. $27,27 \%$, w 2012 r. $25,71 \%$, w 2013 r. $25,90 \%$, w 2014 r. 27,34\%, w 2015 r. 22,63\%, w 2016 r. 25,15\%. Należy wskazać, że zaistniałe zmiany były bardzo silnie powiązane ze stopniowym procesem redukcji potencjału polskiej floty rybackiej na Morzu Bałtyckim.

Tabela 3. Tonaż $[\mathrm{GT}]$ oraz moc silników $[\mathrm{kW}]$ floty zarejestrowanej w porcie Władysławowo na tle całości polskiej floty kutrowej operującej na Morzu Bałtyckim w latach 2004-2016

\begin{tabular}{|c|c|c|c|c|}
\hline \multirow{2}{*}{ Rok } & \multicolumn{2}{|c|}{ Tonaż floty kutrowej [GT] } & \multicolumn{2}{c|}{$\begin{array}{c}\text { Moc silników floty kutrowej } \\
\text { [kW] }\end{array}$} \\
\cline { 2 - 5 } & Władysławowo & Całość floty & Władysławowo & Całość floty \\
\hline 2004 & 7927 & 33040 & 21721 & 95332 \\
\hline 2005 & 5092 & 19848 & 15695 & 62842 \\
\hline 2006 & 4782 & 17643 & 15126 & 56488 \\
\hline 2007 & 4817 & 17127 & 15502 & 55204 \\
\hline 2008 & 4900 & 15716 & 15864 & 50789 \\
\hline 2009 & 3457 & 12887 & 11736 & 42470 \\
\hline 2010 & 4016 & 11797 & 11769 & 38197 \\
\hline 2011 & 4184 & 11640 & 11743 & 37032 \\
\hline 2012 & 3990 & 11644 & 10914 & 36186 \\
\hline 2013 & 4151 & 12205 & 11004 & 36210 \\
\hline 2014 & 4531 & 12323 & 11666 & 36247 \\
\hline $2015^{*}$ & 4656 & 13796 & 12384 & 42714 \\
\hline $2016^{*}$ & 4511 & 13116 & 11964 & 39724 \\
\hline
\end{tabular}

* Jednostki powyżej 12 m długości

Źródło: Morska Gospodarka Rybna w latach 2004-2016, (2005-2017), Gdynia: Morski Instytut Rybacki.

Zawarte $\mathrm{w}$ tabeli 3 dane, odnoszące się do tonażu zarejestrowanych we Władysławowie jednostek, wykazują w badanym okresie dużą zmienność związaną z dwoma czynnikami. Pierwszym z nich była postępująca kasacja floty, drugim natomiast zmiany natury organizacyjnej, polegające na modyfikacji klasyfikacji długości kutrów i łodzi operujących na Morzu Bałtyckim. W przypadku pierwszego analizowanego 2004 roku osiagnięto względem całej floty najniższy wynik $23,99 \%$. Następne lata cechowały się wskazaną powyżej zmiennościa, przy czym najwyższą wartość uzyskano w 2014 roku (36,77\%). W 2005 r. tonaż jednostek zarejestrowanych we Władysławowie stanowił $25,65 \%$ wszystkich polskich 
kutrów operujących na Morzu Bałtyckim, w 2006 r. 27,10\%, w 2007 r. 28,13\%, w 2008 r. 31,18\%, w 2009 r. 26,83\%, w 2010 r. 34,04\%, w 2011 r. 35,95\%, w 2012 r. $34,27 \%$, w 2013 r. 34,01\%, w 2014 r. 36,77\%, w 2015 r. 33,75\%, w 2016 r. 34,39\%).

W przypadku analizy łącznej mocy silników [kW] floty bazującej we Władysławowie na tle wszystkich polskich kutrów eksploatowanych na Morzu Bałtyckim, w badanym okresie, miały miejsce bardzo duże wahania prezentowanej w tabeli 3 wartości. Należy wskazać, że najniższy wynik osiągnięto w 2004 roku, co było związane z dużą liczebnością floty (22,78\%) (S. Szostak i in., 2005, s. 18). Najwyższy udział władysławowskich jednostek w badanej kategorii miał natomiast miejsce w 2014 roku. W 2005 r. łączna moc jednostek zarejestrowanych we Władysławowie stanowiła 24,98\% mocy wszystkich polskich kutrów eksploatowanych na Morzu Bałtyckim, w 2006 r. 26,78\%, w 2007 r. 28,08\%, w 2008 r. $31,24 \%$, w 2009 r. $27,63 \%$, w 2010 r. 30,81\%, w 2011 r. $31,71 \%$, w 2012 r. $30,16 \%$, w 2013 r. 30,39\%, w 2014 r. 32,18\%, w 2015 r. 28,99\%, w 2016 r. 30,12\%.

\section{Zakończenie}

Polskie rybołówstwo kutrowe na Morzu Bałtyckim od czasu przystąpienia Polski do Unii Europejskiej w 2004 roku przeszło bardzo daleko posuniętą restrukturyzację. Złomowano niemal wszystkie jednostki, których armatorzy dobrowolnie zgłosili je do procesu kasacji, tym samym nakład dostosowano do przyjętych założeń redukcji potencjału połowowego, aczkolwiek struktura floty nadal wskazuje jej niezrównoważenie w stosunku do zasobów. Na przestrzeni lat 2004-2016 doszło do diametralnego zmniejszenia liczby kutrów pozostających w eksploatacji, pomiomo dokonanych prac modernizacyjnych polegających na przedłużaniu jednostek oraz wymianie silników zmniejszyły się również tonaż oraz moc floty. Niestety, zjawisko to, obok silnych tendencji mających na celu poprawę efektywności i realne ograniczenie szkodliwego wpływu rybołówstwa na środowisko naturalne, ma także negatywne skutki. Dotyczą one w dużej mierze ograniczenia dostępu do surowca, co nie jest powiązane z nakładem lecz ze zmniejszoną liczbą jednostek, z którymi można kooperować oraz drastycznego obniżenia zatrudnienia w rybołówstwie, co jest niewątpliwie efektem postępującej automatyzacji. W całym systemie gospodarki rybnej bardzo ważną rolę odgrywa zaprezentowane na łamach niniejszego artykułu rybołówstwo kutrowe zarejestrowane w portach Półwyspu Helskiego. Opisywana flota, stacjonująca w portach Półwyspu Helskiego, korzysta z ich dogodnego położenia zapewniającego względnie łatwy dostęp do obfitych ławic ryb. Bardzo korzystne rozmieszczenie portów w Helu i Władysławowie nie wymaga pokonywania dużych odległości między portem a łowiskami, co niewątpliwie wpływa na obniżenie kosztów utrzymania floty kutrowej. 


\section{Bibliografia}

1. Budny T., Kieliszewska M., Krupska J., (2017) Morska gospodarka rybna w latach 2015-2016, Gdynia: Morski Instytut Rybacki.

2. Duda D., Wandtke B., (1993), Port Hel. Przyczynek do 100-letniej historii, Gdynia: Urząd Morski w Gdyni.

3. Jackowski E. (2005) Porty i przystanie rybackie wschodniego wybrzeża - stan i perspektywy rozwoju. cz. 1, Wiadomości Rybackie, 5-6, 9-11.

4. Kuzebski E., (2007) Redukcja polskiej floty rybackiej 2004-2006, Wiadomości Rybackie, 3-4, 8-10.

5. Szostak S., Kuzebski E., Budny T., (2005) Morska Gospodarka Rybna w 2004r., Gdynia: Morski Instytut Rybacki.

6. Szostak S., Kuzebski E., Budny T., (2006) Morska Gospodarka Rybna w 2005r., Gdynia: Morski Instytut Rybacki.

7. Szostak S., Kuzebski E., Budny T., (2007) Morska Gospodarka Rybna w 2006r., Gdynia: Morski Instytut Rybacki.

8. Szostak S., Kuzebski E., Rakowski M., (2008) Morska Gospodarka Rybna w 2007r., Gdynia: Morski Instytut Rybacki.

9. Szostak S., Kuzebski E., Rakowski M., (2009) Morska Gospodarka Rybna w 2008r., Gdynia: Morski Instytut Rybacki.

10. Szostak S., Rakowski M., Budny T., (2010) Morska Gospodarka Rybna w 2009r., Gdynia: Morski Instytut Rybacki.

11. Szostak S., Rakowski M., Budny T., (2011) Morska Gospodarka Rybna w 2010r., Gdynia: Morski Instytut Rybacki.

12. Szostak S., Rakowski M., Budny T., (2012) Morska Gospodarka Rybna w 2011r., Gdynia: Morski Instytut Rybacki.

13. Szostak S., Rakowski M., Budny T., (2013) Morska Gospodarka Rybna w 2012r., Gdynia: Morski Instytut Rybacki.

14. Szostak S., Rakowski M., Budny T., (2014) Morska Gospodarka Rybna w 2013r., Gdynia: Morski Instytut Rybacki.

15. Szostak S., Rakowski M., Budny T., (2015) Morska Gospodarka Rybna w 2014r., Gdynia: Morski Instytut Rybacki.

16. Szostak S., (2005) Wyniki gospodarki rybnej w 2004r., Wiadomości Rybackie, 9-10, 9-11.

17. Szostak S., (2006) Wyniki gospodarki rybnej w 2005 r., Wiadomości Rybackie, 7-8, 10-13.

18. Szostak S., (2007) Wyniki gospodarki rybnej w 2006 r., Wiadomości Rybackie, 910, 10-14.

19. Szostak S., (2008) Wyniki gospodarki rybnej w 2007 r., Wiadomości Rybackie, 9$10,5-9$.

20. Szostak S., (2009) Wyniki gospodarki rybnej w 2008 r., Wiadomości Rybackie, 910, 8-14.

21. Szostak S., (2012) Wyniki gospodarki rybnej w 2011 r., Wiadomości Rybackie, 7-8, 5-10.

22. Szostak S., (2014) Wyniki gospodarki rybnej w 2013 r., Wiadomości Rybackie, 7-8, 16-21. 
23. Szostak S., (2015) Wyniki gospodarki rybnej w 2014 r., Wiadomości Rybackie, 7-8, 14-19.

24. 50 lat „Szkunera”, (2005) Wiadomości Rybackie, 3-4, 18.

25. https://mgm.gov.pl/pl/rybolowstwo/ [dostęp: 05.10.2018].

26. https://www.gov.pl/gospodarkamorska/rejestr- statkow-rybackich [dostęp: 05.10.2018].

\section{CUTTER FLEET OF THE HEL PENINSULA PORTS 2004-2016}

\section{Summary}

The aim of this article is to present phenomena that took place in the cutter fleet (till 2015 cutters 15 meters in length, from 2015 cutters 12 meters in length) spread on the Hel Peninsula in the years 2004-2016. The first part presents general indicators that characterize the Polish cutter fleet on the Baltic Sea and placement of cutters expressed in pieces in three researched ports: Hel, Jastarnia ora in Władysławowo. The second part of the article presents detailed data regarding units registered in the Hel port. Discussed is the share of the fleet in the cutter segment based on the Peninsula and in relation to all units exploited in the Baltic Sea, total tonnage expressed in GT and power expressed in $\mathrm{kW}$. The third part of the article will present a similar analysis, although carried out for units based in Jastarnia. The fourth part discusses identical data for cutters based in Władysławowo.

Keywords: fisheries, fishing, maritime overfishing

Nie kasować nic poniżej tej linii 

